\title{
Clinical communication skills and professionalism education are required from the beginning of medical training - a point of view of family physicians
}

Camila Ament Giuliani dos Santos Franco ${ }^{1,2^{*}}$, Renato Soleiman Franco ${ }^{2,3}$, José Mauro Ceratti Lopes ${ }^{4,5^{\wedge}}$, Milton Severo $2,6,7$ and Maria Amélia Ferreira ${ }^{2,8}$

\begin{abstract}
Background: The Brazilian undergraduate medical course is six years long. As in other countries, a medical residency is not obligatory to practice as a doctor. In this context, this paper aims to clarify what and when competencies in communication and professionalism should be addressed, shedding light on the role of university, residency and post-residency programmes.

Methods: Brazilian family physicians with diverse levels of medical training answered a questionnaire designed to seek a consensus on the competencies that should be taught (key competencies) and when students should achieve them during their medical training. The data were analysed using descriptive statistics and correlation tests.

Results: A total of seventy-four physicians participated; nearly all participants suggested that the students should achieve communication and professionalism competencies during undergraduate study (twenty out of thirty competencies $-66.7 \%$ ) or during residency (seven out of thirty competencies - 23.33\%). When competencies were analysed in domains, the results were that clinical communication skills and professionalism competencies should be achieved during undergraduate medical education, and interpersonal communication and leadership skills should be reached during postgraduate study.

Conclusion: The authors propose that attainment of clinical communication skills and professionalism competencies should be required for undergraduate students. The foundation for Leadership and Interpersonal Abilities should be particularly formed at an undergraduate level and, furthermore, mastered by immersion in the future workplace and medical responsibilities in residency.
\end{abstract}

Keywords: Communication, Medical education, Professionalism, Primary care, Family physician

\section{Background}

Better communication competencies and professionalism are crucial for better healthcare outcomes $[1,2]$. Effective communication is central to the quality of healthcare [3] because it promotes shared decision-making and improves adherence to therapeutic instructions, to both the patients'

\footnotetext{
* Correspondence: camilaament@gmail.com

Deceased

${ }^{1}$ School of Medicine (discipline of Family Medicine), Pontifical University of Paraná, Curitiba, Brazil

${ }^{2}$ Department of Medical Education and Simulation, Faculty of Medicine, University of Porto, Alameda Prof. Hernâni Monteiro, 4200-319 Porto, Portugal Full list of author information is available at the end of the article
}

and the physicians' satisfaction [4-7]. Professionalism is also important and involves competencies that enable doctors to serve the patients' interests above their own by exercising altruism, accountability, excellence, duty, service, honour, integrity and respect for others [8]. Communication competencies and professionalism have as a common core the building of adequate relationships among patients and their families, the community, and healthcare workers.

The status of teaching communication skills, as stated by Brown (2008), has changed from 'nice to know' to 'need to know' [9]. Numerous studies conducted in 
different countries and settings have demonstrated the effectiveness of teaching communication and professionalism during undergraduate $[10,11]$ and postgraduate medical training $[12,13]$ for the promotion of good outcomes for patients. Communication skills and professionalism are related to the more influential aspects of healthcare provided by primary care doctors [14] and they are described as being among the fundamental tools for family physicians [4], particularly for the treatment of chronic diseases such as diabetes and hypertension. Undergraduate training in family medicine can promote the improvement of competencies related to communication and professionalism [15], and as the majority of healthcare is initially delivered in the primary care setting, medical education must consider and empower this setting for medical training [16].

Brazilian medical training involves six years of undergraduate courses followed by a residency programme and continued education and training. In Brazil, the residency programme is not obligatory, and after medical school, a physician can work as a doctor without specialisation. Since 2001, communication competencies and professionalism have been defined among outcomes in the Brazilian national guidelines for medical undergraduates [17]. In 2014, the current guideline, Diretrizes Curriculares Nacionais para o Curso de Graduação em Medicina (National Curricular Guidelines for the Medicine Course), reinforced communication competencies and professionalism [18]. The teaching of communication competencies and professionalism are now being fostered in Brazilian schools of medicine, where curricula have been structured to include these topics [19].

Family physicians and the primary care setting have become more important in the public health system and in undergraduate and postgraduate medical education in Brazil [18]. Therefore, considering the importance of teaching communication and professionalism to primary care physicians and the importance of the government's stimuli to include this setting in medical training, the viewpoint of family physicians with regard to medical education has become important for the development of teaching these topics.

A variety of globally accepted documents on medical training have pointed to professionalism and communication competencies as being the competencies that must be achieved [18, 20-28]. Despite being seen as crucial, the teaching, learning and practice of these competencies can be incomplete or even missing among medical students and physicians [29]. Finding consensus on these competencies, and aggregating them into domains or major themes, and then determining the most appropriate time to attain these competencies should help with the design of teaching strategies. Drawing on the importance of family medicine in medical schools and primary care along with the inclusion of the expertise of family physicians in the development of these competencies, this study aims to do the following: 1 ) define key competencies (KCs) in communication and 2) shed light on when communication and professionalism KCs should be achieved during medical training.

\section{Methods}

\section{Survey design}

The research was performed between January and November 2015. It was developed in three phases: 1) thematic organisation of communication skill competencies and the definition of communication KCs, 2) confirmatory analysis of the themes within communication competencies, and 3) investigation of when family physicians think competencies in professionalism and communication should be achieved. The definition of $\mathrm{KCs}$ for professionalism was based on a systematic review by Birden et al. [30], which our research team used to conduct a thematic analysis of relevant papers on professionalism from Birden et al.'s review (the results of which we have already published and presented at conferences [31]). Thus, the first two phases of this study apply to communication and the third phase (when to achieve) is in regard to both communication and professionalism. The participants answered questions about the clustering of the communication competencies, and the professionalism competencies were touched on in part when they answered questions about when the competencies should be achieved. The results, discussion and conclusions of the clustering of competencies are only applied to the communication competencies.

The thematic organisation of communication competencies KCs for communication were thematically organised by examining medical training reference documents and reviewing the consensus statements of clinical communication skills. This included a total of nine documents: six medical training guides from the UK, Germany, the United States, Canada, Australia and Brazil; and three documents focused on communication skills, the Calgary-Cambridge Guide, the Kalamazoo Consensus Statement and the European consensus on learning objectives for a core communication curriculum in health care professions [18, 20-28].

Three researchers performed a thematic organisation of these documents using a three-step process. The three researchers each have experience in medical education and one has been involved in medical training and training of trainers in communication and patient-centred medicine, for more than thirty years. Two are family physicians and one is a psychiatrist. In the first step, all competencies and learning outcomes related to communication ('fragments') were identified and highlighted. 
In the second step, the fragments were grouped by content similarity, and descriptive themes were generated without any preconceived determinations on the part of the researchers. These descriptive themes became the KCs, which needed to be representative of the core meanings of the fragments' contents (the fragments corresponded to the highlighted learning outcomes related to communication in the reference documents). Once these $\mathrm{KCs}$ for communication were determined, they were grouped into three domains: Clinical Communication Skills (CCS), closely related to patient care; Interpersonal Communication (IC), closely related to teamwork, multidisciplinary teams and colleagues; and Leadership.

The second phase used Qualtrics ${ }^{\mathrm{Tm}}$, a web-based survey system. The survey was sent by email to 213 doctors from all regions of Brazil between April and June 2015 (Additional file 1- Survey Questionnaire). The recipients had participated in courses for trainers in family medicine under three types of professional activities: preceptors, faculty members and medical doctors. The questionnaire included three sections: 1) collection of demographic characteristics, professional activities and an estimation of the time frame within which each doctor had achieved their own competencies in communication skills and professionalism; 2) confirmation of the communication themes (KCs) defined by the researchers and 3) their point of view on the optimal time to require attainment of these $\mathrm{KCs}$, i.e. at the undergraduate level, during residency or after residency.

In the second section of the questionnaire, to confirm if the competencies were appropriately represented by the KCs, the fragments were presented to 74 subjects who were asked to choose a KC that best represented the fragment's meaning. Among the choices was one or more of the KCs as well as others not included in the KCs.

\section{Statistical analyses}

The categorical numerical variables were described using counts (percentages) and means (SD) or medians (25th percentile and 75th percentile). To find the groups of fragments that corresponded to each $\mathrm{KC}$, the participants' responses were evaluated. To identify the response patterns, we used hierarchical clustering with Manhattan distance. The number of clusters was identified using fusion coefficients.

To find the best time for each $\mathrm{KC}$ to be attained, all $K C s$ in each domain were scored from 0 to 100 . The Mann-Whitney test and Spearman's rank correlation were used to determine whether there were significant associations between any KCs and the overall scores. Data were analysed using SPSS, Version 22.0.

\section{Results}

Characteristics of the sample's subjects

The 74 (34.6\%) participants ranged in age from 27 to 59 years old, with a mean age of 37.9 years $(\mathrm{SD}=7.6)$. They had graduated from medical school 13.6 (mean) years ago ( $\mathrm{SD}=7.8$ ), between 1980 and 2012, and 51.4\% were women. Ninety-three per cent had worked as a family physician for 12.2 (mean) years $(\mathrm{SD}=8.0), 91.9 \%$ had worked as a preceptor for 5.4 (mean) years $(\mathrm{SD}=$ 5.7 ) and $71.4 \%$ had worked as a faculty member for 6.0 years (mean) $(\mathrm{SD}=5.6)$.

Most of the participants $(72.9 \%)$ had completed residency programmes in family medicine that certified them as family physician specialists and $18.9 \%$ were family physician specialists without a residency. Only $8 \%$ were not family physician specialists but they had worked in or taught primary healthcare courses. Forty-six per cent had a master's degree, $5.4 \%$ had a doctoral degree and $1.3 \%$ had a post-doctorate degree.

\section{The definition of KCs in communication}

The 9 documents examined for KCs contained 88 communication competencies (highlighted fragments) [18, 20-28]. Thirty-one competencies (fragments) were identical or very similar across the documents, leaving fifty-seven competencies. The thematic organisation categorised these 57 fragments into $18 \mathrm{KCs} ; 11 \mathrm{KCs}$ were conceptually related to CCS, 5 were related to IC and 2 were related to Leadership.

When the participants chose the KCs that best represented a particular competency's idea and meaning, the answers generated groups of competencies that were associated with the KCs (there was one or more competencies related to each $\mathrm{KC}$ ). The confirmation of these KCs by the family physicians and the percentage of agreement are shown in Table 1, where frequency means how often the whole group of competencies were related to the KC for CCS. For the competencies in IC (10 competencies) and in Leadership (7 competencies), the aggregation of competencies into groups was not considered because of the small number of items. There were no fragments not represented by any $\mathrm{KC}$.

The definition of KCs for professionalism was based on the articles referred to in the systematic review by Birden et al. [30], as relevant to this theme. The articles were read in full and the competencies were extracted from the texts using thematic analysis [31]. Altruism; accountability; humanistic values; ethics; social commitment; commitment to excellence and advancement of knowledge; reflective thinking; dealing effectively with uncertainty and changes; collaboration and teamwork; and expert knowledge were related to the competencies of professionalism. The competencies of collaboration and teamwork were cited in two of the nine papers 
Table 1 The percentage of agreement among Family Physicians on Key Competencies and the competencies represented by each group of Key Competencies

\begin{tabular}{|c|c|c|c|c|c|c|c|c|c|c|c|c|}
\hline \multirow[t]{2}{*}{ Clinical Communication Skills (Key Competencies) } & \multicolumn{12}{|c|}{ Group of Competencies (Fragments) (CCS)* } \\
\hline & 1 & 2 & 3 & 4 & 5 & 6 & 7 & 8 & 9 & 10 & 11 & 12 \\
\hline Communicate effectively according to given roles & $44 \%$ & $3 \%$ & $2 \%$ & $1 \%$ & $7 \%$ & $7 \%$ & $5 \%$ & $3 \%$ & $2 \%$ & $0 \%$ & $0 \%$ & $0 \%$ \\
\hline Establish a therapeutic and professional relationship & $4 \%$ & $1 \%$ & $42 \%$ & $0 \%$ & $2 \%$ & $0 \%$ & $1 \%$ & $0 \%$ & $0 \%$ & $5 \%$ & $0 \%$ & $0 \%$ \\
\hline Build a suitable relationship & $3 \%$ & $49 \%$ & $29 \%$ & $6 \%$ & $7 \%$ & $6 \%$ & $1 \%$ & $2 \%$ & $0 \%$ & $0 \%$ & $0 \%$ & $0 \%$ \\
\hline Involve the bio-psycho-social context & $1 \%$ & $0 \%$ & $0 \%$ & $7 \%$ & $2 \%$ & $8 \%$ & $0 \%$ & $2 \%$ & $0 \%$ & $0 \%$ & $2 \%$ & $84 \%$ \\
\hline Understand the perspective of the patient and his or her family & $2 \%$ & $1 \%$ & $3 \%$ & $63 \%$ & $6 \%$ & $2 \%$ & $5 \%$ & $2 \%$ & $6 \%$ & $0 \%$ & $2 \%$ & $11 \%$ \\
\hline Adapt communication according to the patient and his or her family & $18 \%$ & $5 \%$ & $3 \%$ & $3 \%$ & $1 \%$ & $71 \%$ & $8 \%$ & $2 \%$ & $2 \%$ & $0 \%$ & $3 \%$ & $0 \%$ \\
\hline Engage patients and families to share in decision-making & $3 \%$ & $27 \%$ & $9 \%$ & $10 \%$ & $11 \%$ & $0 \%$ & $10 \%$ & $0 \%$ & $0 \%$ & $5 \%$ & $63 \%$ & $0 \%$ \\
\hline Support decision-making based on the needs and interests of the patient & $1 \%$ & $8 \%$ & $8 \%$ & $7 \%$ & $13 \%$ & $3 \%$ & $15 \%$ & $4 \%$ & $0 \%$ & $79 \%$ & $12 \%$ & $5 \%$ \\
\hline Structure and organize communication/clinical interviews & $6 \%$ & $2 \%$ & $0 \%$ & $1 \%$ & $37 \%$ & $1 \%$ & $6 \%$ & $85 \%$ & $2 \%$ & $5 \%$ & $1 \%$ & $0 \%$ \\
\hline Communicate bad news appropriately & $5 \%$ & $0 \%$ & $0 \%$ & $2 \%$ & $0 \%$ & $2 \%$ & $4 \%$ & ०\% & $87 \%$ & ०\% & ०\% & $0 \%$ \\
\hline None of the Key Competencies & $4 \%$ & $3 \%$ & $2 \%$ & $1 \%$ & $11 \%$ & $0 \%$ & $3 \%$ & $2 \%$ & $0 \%$ & $5 \%$ & $0 \%$ & $0 \%$ \\
\hline
\end{tabular}

Competency (Fragments)

Communicate effectively with patients, families and the public

Communicate effectively in wider roles including health advocacy, teaching, assessing and appraising. Communicate effectively about ethical issues with patients and family

Communicate effectively in various roles, for example, as patient advocate, teacher, manager or improvement leader

Uses effective and efficient communication and management strategies

Demonstrate by listening, sharing and responding, the ability to communicate clearly, sensitively and effectively with patients and their family/careers

Communicate clearly, sensitively and effectively with patients, their relatives or other carers, and colleagues from the medical and other professions, by listening, sharing and responding

Demonstrate by listening, sharing and responding, the ability to communicate clearly, sensitively and effectively with patients and their family/careers

Building relationship (Using appropriate non-verbal behaviour, Developing rapport and Involving the patient)

Shaping of relationship: involves the patient in the interaction using a patientcentered approach

Recognizes the patient as a partner in shaping a relationship

Involves the patient in the interaction to establish a therapeutic relationship using a patient-centered approach.

Relates to the patient respectfully including ensuring confidentiality, privacy and autonomy...

Establish professional therapeutic relationships with patients and their families

Create and sustain a therapeutic, ethical relationships with patients

Gathering information (Exploration of patient's problems and Additional skills for understanding the patient's perspective)

Encourage the patient to express own ideas, concerns, expectations and feelings and accepts legitimacy of patients views and feeling

Understand the Patient's Perspective

Gather information

Information: effectively collects the relevant information for the reasoning and decision-making process

Effectively collects relevant information for reasoning and decision making 
Table 1 The percentage of agreement among Family Physicians on Key Competencies and the competencies represented by each group of Key Competencies (Continued)

7

8

10

12

Interpersonal Communication (Key Competencies)

Work effectively in multidisciplinary team, adapting to the particularities of each team and given roles

Perform consulting, helping colleagues, other professionals, and the healthcare system

Communicate effectively to promote understanding and resolve conflicts, aiming to ensure the success of teamwork

Perform teamwork, aiming to ensure patient safety

Communicate about ethical issues with other health professionals

None of the Key Competencies
Initiating the session (Establishing initial rapport and Identifying the reason(s) for the consultation)

Open the Discussion

Communication in the doctor-patient relationship: orients her communication behaviour along the actual concerns and the personality of the patient

Social behaviour and communication: adapts her social behaviour and communication to different social contexts and communication partners.

Adapts own communication to the level of understanding and language of the patient, uses techniques aproppriates for this

Explanation and planning (Providing the correct amount and type of information, Aiding accurate recall and understanding...)

Information: effectively communicates the relevant information for the reasoning and decision-making process

Effectively communicates relevant information for reasoning and decision making. Gives information to the patient in a timely, comprehensive and meaningful manner

Elicit and synthesize accurate and relevant information, incorporating the perspectives of patients and their families

Shapes a conversation from beginning to end with regard to structure (e.g. introduction, initiating the conversation, gathering and giving information, planning, closing interview, setting up next meeting; time management)

Providing structure (Making organization overt And Attending to flow)

Communicate appropriately with difficult or violent patients; people with mental illness and vulnerable patients//Communicate appropriately in difficult circumstances, such as when breaking bad news, and when discussing sensitive issues, such as alcohol consumption, smoking or obesity

Recognizes difficult situations and communication challenges and deals with them sensitively and constructively

;... developing plans that reflect the patient's health care needs and goals

Involve patients in decision-making and planning their treatment, including communicating risk and benefits of management options.

Engage patients and their families...

Share information

Explanation and planning (Achieving a shared understanding: incorporating the patient's perspective and Planning: shared decision making)

Share health care information and plans with patients and their families

Elicits and explores the content of the patient's bio-psycho-social history.

Number (IC)

$\begin{array}{llllllllll}1 & 2 & 3 & 4 & 5 & 6 & 7 & 8 & 9 & 10 \\ 72 \% & 30 \% & 87 \% & 55 \% & 25 \% & 9 \% & 12 \% & 0 \% & 0 \% & 0 \% \\ 11 \% & 26 \% & 0 \% & 0 \% & 39 \% & 82 \% & 6 \% & 5 \% & 0 \% & 0 \% \\ 11 \% & 19 \% & 13 \% & 30 \% & 6 \% & 0 \% & 65 \% & 11 \% & 82 \% & 18 \% \\ 6 \% & 7 \% & 0 \% & 10 \% & 9 \% & 0 \% & 6 \% & 79 \% & 0 \% & 5 \% \\ 0 \% & 4 \% & 0 \% & 0 \% & 0 \% & 0 \% & 0 \% & 0 \% & 18 \% & 77 \% \\ 0 \% & 15 \% & 0 \% & 5 \% & 19 \% & 9 \% & 11 \% & 5 \% & 0 \% & 0 \%\end{array}$


Table 1 The percentage of agreement among Family Physicians on Key Competencies and the competencies represented by each group of Key Competencies (Continued)

\begin{tabular}{|c|c|c|c|c|c|c|}
\hline Number (IC) & \multicolumn{6}{|c|}{ Competency (Fragments) } \\
\hline 1 & \multicolumn{6}{|c|}{$\begin{array}{l}\text { Work effectively with physicians and other colleagues in the health care } \\
\text { professions }\end{array}$} \\
\hline 2 & \multicolumn{6}{|c|}{$\begin{array}{l}\text { Communicate effectively with physicians, other health professionals and } \\
\text { health-related agencies }\end{array}$} \\
\hline 3 & \multicolumn{6}{|c|}{$\begin{array}{l}\text { Team building and working in a team: adapts her behaviour to different } \\
\text { phases of team building and efficiently shapes her working style to contribute } \\
\text { to a successful team }\end{array}$} \\
\hline 4 & \multicolumn{6}{|c|}{ Shows ability to communicate effectively in multi-professional teams } \\
\hline 5 & \multicolumn{6}{|c|}{$\begin{array}{l}\text { Contribute to the improvement of health care delivery in teams, organizations, } \\
\text { and systems }\end{array}$} \\
\hline 6 & \multicolumn{6}{|c|}{$\begin{array}{l}\text { Act in a consultative role to other physicians, health-related agencies and } \\
\text { policy-makers }\end{array}$} \\
\hline 7 & \multicolumn{6}{|c|}{$\begin{array}{l}\text { Work with physicians and other colleagues in the healthcare professions } \\
\text { to promote understanding, manage differences, and resolve conflicts }\end{array}$} \\
\hline 8 & \multicolumn{6}{|c|}{$\begin{array}{l}\text { Demonstrate by listening, sharing and responding, the ability to communicate } \\
\text { clearly, sensitively and effectively with doctors and other health professionals. }\end{array}$} \\
\hline 9 & \multicolumn{6}{|c|}{$\begin{array}{l}\text { Hand over the care of a patient to another health care professional to } \\
\text { facilitate continuity of safe patient care }\end{array}$} \\
\hline 10 & \multicolumn{6}{|c|}{ Communicate effectively about ethical issues with health care professionals. } \\
\hline \multirow[t]{2}{*}{ Leadership (Key Competencies) } & \multicolumn{6}{|c|}{ Number (Leadership) } \\
\hline & 1 & 2 & 3 & 5 & 6 & 7 \\
\hline Demonstrate basic leadership skills & $94 \%$ & $82 \%$ & $80 \% \quad 73 \%$ & $100 \%$ & $24 \%$ & $14 \%$ \\
\hline Engage in the management of human and health care resources & $0 \%$ & $9 \%$ & $5 \% \quad 20 \%$ & $0 \%$ & $76 \%$ & $81 \%$ \\
\hline None of the Key Competencies & $6 \%$ & $9 \%$ & $15 \% \quad 7 \%$ & $0 \%$ & $0 \%$ & $5 \%$ \\
\hline Number (Leadership) & \multicolumn{6}{|c|}{ Competency (Fragments) } \\
\hline 1 & \multicolumn{6}{|c|}{ Demonstrate leadership in professional practice } \\
\hline 2 & \multicolumn{6}{|c|}{ Work with other care providers as a team leader or member } \\
\hline 3 & \multicolumn{6}{|c|}{ Describe the principles and practice of leadership in health care. } \\
\hline 4 & \multicolumn{6}{|c|}{$\begin{array}{l}\text { Leadership: shows basic competencies in leadership skills and supports the } \\
\text { development and maintenance of the teamwork with her behavior }\end{array}$} \\
\hline 5 & \multicolumn{6}{|c|}{ Shows basic competencies in leadership skills } \\
\hline 6 & \multicolumn{6}{|c|}{ Engage in the stewardship of health care resources. } \\
\hline 7 & \multicolumn{6}{|c|}{ Manage career planning, finances, and health human resources in a practice } \\
\hline
\end{tabular}

reviewed for professionalism, but almost all of the documents related to communication included collaboration and teamwork in the fields of interpersonal communication or leadership. Therefore, collaboration and teamwork were presented in the communication competencies, namely in the KCs for IC and Leadership. Consequently, there were 9 professionalism themes represented by 12 KCs (Table 2).

\section{When students should achieve professionalism and communication competencies}

Table 2 shows the participants' answers regarding when students should achieve each KC. Of the $30 \mathrm{KCs}$ (18 for communication and 12 for professionalism), the subjects reported that $20(66.7 \%)$ of the KCs should be achieved during undergraduate medical education, 7 (23.3\%) during residency, 1 (3.3\%) after residency, 1 (3.3\%) during residency or undergraduate education and 1 (3.33\%) during any of these periods.

When the KCs were analysed by the domains (three domains each for communication, CCS, IC and Leadership and one domain for Professionalism), the results showed that the participants believed KCs for CCS and Professionalism should be achieved during undergraduate education, and $\mathrm{KCs}$ for IC and Leadership should be achieved during postgraduate study (residency and postresidency) (see Table 2 ).

The stage of medical training at which the participants reported they had reached professionalism and communication competencies themselves correlated significantly 
Table 2 When students should achieve professionalism and communication competencies

\begin{tabular}{|c|c|c|c|c|c|}
\hline Competency & $\begin{array}{l}\text { Subdomain } \\
\text { Competencies }\end{array}$ & Under graduate \% & FM Residency \% & After Residency \% & $p^{*}$ \\
\hline Communicate effectively according to given roles & CCS & 50.0 & 42.1 & 7.9 & 0.003 \\
\hline Establish a therapeutic and professional relationship & CCS & 35.1 & 54.1 & 10.8 & 0.005 \\
\hline Build a suitable relationship & CCS & 60.5 & 34.2 & 5.3 & $<0.001$ \\
\hline Involve the bio-psycho-social context & CCS & 48.9 & 44.4 & 6.7 & $<0.001$ \\
\hline $\begin{array}{l}\text { Understand the perspective of the patient and his } \\
\text { or her family }\end{array}$ & CCS & 70.6 & 29.4 & 0.0 & 0.016 \\
\hline $\begin{array}{l}\text { Adapt communication according to the patient } \\
\text { and his or her family }\end{array}$ & CCS & 73.8 & 21.4 & 4.8 & $<0.001$ \\
\hline $\begin{array}{l}\text { Engage patients and families to share in } \\
\text { decision-making }\end{array}$ & CCS & 77.8 & 22.2 & 0.0 & $<0.001$ \\
\hline $\begin{array}{l}\text { Support decision-making based on the needs and } \\
\text { interests of the patient }\end{array}$ & CCS & 71.8 & 23.1 & 5.1 & $<0.001$ \\
\hline $\begin{array}{l}\text { Structure and organize communication/clinical } \\
\text { interviews }\end{array}$ & CCS & 59.5 & 38.1 & 2.4 & $<0.001$ \\
\hline Communicate bad news appropriately & CCS & 17.1 & 70.7 & 12.2 & $<0.001$ \\
\hline Inform patients and family adequately & CCS & 52.6 & 42.1 & 5.3 & $<0.001$ \\
\hline $\begin{array}{l}\text { Work effectively in multidisciplinary team, adapting } \\
\text { to the particularities of each team and given roles }\end{array}$ & IC & 19.4 & 69.4 & 11.1 & $<0.001$ \\
\hline $\begin{array}{l}\text { Perform consulting, helping colleagues, other } \\
\text { professionals, and the healthcare system }\end{array}$ & IC & 52.4 & 42.9 & 4.8 & $<0.001$ \\
\hline $\begin{array}{l}\text { Communicate effectively to promote understanding } \\
\text { and resolve conflicts, aiming to ensure the success } \\
\text { of teamwork }\end{array}$ & IC & 16.3 & 53.5 & 30.2 & 0.010 \\
\hline Perform teamwork, aiming to ensure patient safety & IC & 19.5 & 70.7 & 9.8 & $<0.001$ \\
\hline $\begin{array}{l}\text { Communicate about ethical issues with other } \\
\text { health professionals }\end{array}$ & IC & 22.2 & 61.1 & 16.7 & 0.002 \\
\hline Demonstrate basic leadership skills & Leadership & 41.7 & 47.2 & 11.1 & 0.017 \\
\hline $\begin{array}{l}\text { Engage in the management of human and health } \\
\text { care resources }\end{array}$ & Leadership & 7.0 & 37.2 & 55.8 & $<0.001$ \\
\hline $\begin{array}{l}\text { Know and apply ethics, acting with honesty and } \\
\text { respecting ethical and moral values }\end{array}$ & Professionalism & 90.5 & 9.5 & 0.0 & $<0.001$ \\
\hline Act with interest and dedication & Professionalism & 100.0 & 0.0 & 0.0 & $<0.001$ \\
\hline $\begin{array}{l}\text { Prioritize patient's/family's/community's interests } \\
\text { above one's own }\end{array}$ & Professionalism & 64.4 & 26.7 & 8.9 & $<0.001$ \\
\hline $\begin{array}{l}\text { Recognize one's limits and know when to request } \\
\text { support }\end{array}$ & Professionalism & 68.2 & 31.8 & 0.0 & 0.016 \\
\hline Be responsible and careful in one's actions & Professionalism & 69.2 & 30.8 & 0.0 & 0.016 \\
\hline Attempt to promote patient and/or family safety & Professionalism & 89.5 & 7.9 & 2.6 & $<0.001$ \\
\hline $\begin{array}{l}\text { Act according to the highest standards of excellence } \\
\text { and know where to seek knowledge }\end{array}$ & Professionalism & 41.7 & 36.1 & 22.2 & 0.338 \\
\hline $\begin{array}{l}\text { Be empathic and respectful, valuing the feelings } \\
\text { and wishes of colleagues, patients, teachers, and } \\
\text { other professionals }\end{array}$ & Professionalism & 91.9 & 5.4 & 2.7 & $<0.001$ \\
\hline $\begin{array}{l}\text { Consider the beliefs, needs, and views of patients/ } \\
\text { families }\end{array}$ & Professionalism & 81.8 & 15.9 & 2.3 & $<0.001$ \\
\hline Reflect and have good critical skills & Professionalism & 65.9 & 26.8 & 7.3 & $<0.001$ \\
\hline $\begin{array}{l}\text { Deal with uncertainty appropriately, adapting to } \\
\text { different situations and contexts }\end{array}$ & Professionalism & 32.4 & 54.1 & 13.5 & 0.010 \\
\hline Recognize and nurture their own physical and mental health & Professionalism & 87.1 & 9.7 & 3.2 & $<0.001$ \\
\hline
\end{tabular}

$p$ value $<0.05$ was considered statistically significant 
with when they suggested students should achieve these competencies. Subjects who assumed that their professionalism or communication competencies had been achieved in the early stages of their medical training agreed that these competencies should be achieved sooner. Participants who had completed a family medicine residency believed that KCs for CCS should be achieved later. The longer a participant had spent working as a preceptor, the more they agreed that the achievement of KCs in IC should occur later (Table 3).

There were no statistical differences with respect to when the domains of the competencies should be reached when considering the participants' academic degree, gender, age, number of years working as a doctor or number of years working as a faculty member (Table 4).

\section{Discussion}

The 18 communication KCs appeared to be widely acknowledged by family physicians as representative of the 57 competencies. The physicians thought that the KCs for CCS and Professionalism should be achieved during undergraduate medical education and $\mathrm{KCs}$ for IC and Leadership skills should be reached during postgraduate study (residency or after).

\section{The KCs for communication}

The very low selection rate for the option 'None of the Key Competencies (KCs)' and the aggregation of competencies suggested that the KCs were representative of all competencies. The range of agreement about the grouping of the $\mathrm{KC}$ for CCS ranged from $37 \%$ to $87 \%$. Even for the response with the least agreement, 'KC - Structure and organise communication/clinical interviews',

Table 3 Factors associated with the belief that competencies should be developed later or sooner

\begin{tabular}{|c|c|c|c|c|c|c|c|c|c|}
\hline & & Clinical communication skills & & Interpersonal communication & & Leadership & & Professionalism & \\
\hline & N (\%) & Median (P25-P75) & ${ }^{*} \mathrm{p}$ & Median (P25-P75) & ${ }^{*} p$ & Median (P25-P75) & ${ }^{*} p$ & Median (P25-P75) & ${ }^{*} p$ \\
\hline Total & $74(100)$ & $21.43(8.33-40.00)$ & & $50.00(25.00-50.00)$ & & $50.00(31.25-100.00)$ & & $12.50(0.00-21.43)$ & \\
\hline \multicolumn{10}{|l|}{ Gender } \\
\hline Female & $38(51.4)$ & $18.33(7.44-33.33)$ & 0.267 & $50.00(25.00-50.00)$ & 0.647 & $50.00(25.00-100.00)$ & 0.475 & $10.00(0.00-21.43)$ & 0.617 \\
\hline Male & $36(48.6)$ & $23.21(8.33-41.67)$ & & $50.00(25.00-50.00)$ & & $50.00(50.00-100.00)$ & & $14.29(0.00-22.32)$ & \\
\hline \multicolumn{10}{|c|}{ Academic degree } \\
\hline Graduate & $35(47.3)$ & $20.00(0.00-38.75)$ & 0.378 & $50.00(25.00-50.00)$ & 0.482 & $50.00(31.25-100.00)$ & 0.942 & $10.00(0.00-20.71)$ & 0.341 \\
\hline Postgraduate & $39(52.7)$ & $21.43(10.56-40.00)$ & & $50.00(27.08-50.00)$ & & $50.00(43.75-100.00)$ & & $12.50(6.70-23.21)$ & \\
\hline \multicolumn{10}{|c|}{ Has family medicine residency } \\
\hline Yes & $54(73)$ & $23.21(10.28-40.00)$ & 0.029 & $50.00(25.00-50.00)$ & 0.969 & $50.00(50.00-100.00)$ & 0.297 & $12.50(0.00-21.43)$ & 0.729 \\
\hline No & $20(27)$ & $7.74(0.00-28.47)$ & & $43.75(25.22-53.12)$ & & $50.00(25.00-100.00)$ & & $10.00(0.00-23.02)$ & \\
\hline \multicolumn{10}{|c|}{ Developed communication competence during undergraduate period? } \\
\hline Yes & $9(12.2)$ & $0.00(0.00-41.67)$ & 0.001 & $12.50(0.00-37.50)$ & 0.009 & $0.00(0.00-37.50)$ & 0.021 & $0.00(0.00-12.50)$ & 0.112 \\
\hline No & $65(87.8)$ & $21.43(0.00-8.33)$ & & $50.00(33.33-50.00)$ & & $50.00(50.00-100.00)$ & & $12.50(0.00-25.00)$ & \\
\hline \multicolumn{10}{|c|}{ Developed communication competence during family medicine residency? } \\
\hline Yes & $40(54.1)$ & $25.00(10.28-40.00)$ & 0.589 & $42.59(25.00-50.00)$ & 0.489 & $50.00(37.50-100.00)$ & 0.814 & $11.25(0.00-22.32)$ & 0.834 \\
\hline No & $34(45.9)$ & $20.00(8.04-35.00)$ & & $46.31(25.00-50.00)$ & & $50.00(37.50-100.00)$ & & $12.50(0.00-21.43)$ & \\
\hline \multicolumn{10}{|c|}{ Developed communication competence post-residency? } \\
\hline Yes & $30(40.5)$ & $29.29(12.50-41.67)$ & 0.102 & $50.00(40.62-50.00)$ & 0.038 & $50.00(50.00-100.00)$ & 0.398 & $13.39(8.33-24.11)$ & 0.405 \\
\hline No & $44(59.5)$ & $20.00(0.00-33.33)$ & & $33.33(25.00-50.00)$ & & $50.00(25.00-100.00)$ & & $10.00(0.00-21.43)$ & \\
\hline \multicolumn{10}{|c|}{ Developed professionalism during undergraduate period? } \\
\hline Yes & $29(39.2)$ & $10.00(0.00-21.43$ & 0.002 & $33.33(18.12-50.00)$ & 0.007 & $50.00(25.00-100.00)$ & 0.723 & $8.33(0.00-14.29)$ & 0.009 \\
\hline No & $45(60.8)$ & $30.00(14.29-41.67)$ & & $50.00(33.33-56.25)$ & & $50.00(50.00-100.00)$ & & $14.29(6.25-28.57)$ & \\
\hline \multicolumn{10}{|c|}{ Developed professionalism during family medicine residency? } \\
\hline Yes & $40(54.1)$ & $18.33(8.33-34.72)$ & 0.442 & $50.00(25.00-50.00)$ & 0.830 & $50.00(25.00-100.00)$ & 0.448 & $12.50(0.00-21.43)$ & 0.838 \\
\hline No & $34(45.9)$ & $21.43(7.44-41.25)$ & & $50.00(25.00-50.00)$ & & $50.00(50.00-100.00)$ & & $10.00(0.00-24.11)$ & \\
\hline \multicolumn{10}{|c|}{ Developed professionalism post-residency? } \\
\hline Yes & $25(33.8)$ & $35.71(16.67-50.00)$ & 0.011 & $50.00(37.50-75.00)$ & 0.016 & $50.00(50.00-100.00)$ & 0.443 & $14.29(0.00-33.33)$ & 0.087 \\
\hline No & $49(66.2)$ & $16.67(0.00-30.00)$ & & $37.50(25.00-50.00)$ & & $50.00(25.00-100.00)$ & & $10.00(0.00-21.43)$ & \\
\hline
\end{tabular}

$p$ value $<0.05$ was considered statistically significant 
Table 4 The association between the number of years working and the later development of competency

\begin{tabular}{lllll}
\hline & Clinical communication skills & Interpersonal communication & Leadership & Professionalism \\
\hline & $r(p$-value $)$ & $r(p$-value $)$ & $r(p$-value $)$ & $r(p$-value $)$ \\
Years as faculty & $-0.212(0.139)$ & $-0.200(0.172)$ & $-0.286(0.073)$ & $-0.169(0.242)$ \\
Years as preceptor & $0.114(0.356)$ & $0.263(0.033)$ & $-0.032(0.821)$ & $0.053(0.666)$ \\
Years as medical doctor & $-0.011(0.930)$ & $-0.034(0.782)$ & $-0.084(0.543)$ & $-0.111(0.362)$ \\
Age & $-0.012(0.922)$ & $0.086(0.470)$ & $-0.169(0.204)$ & $0.069(0.557)$ \\
\hline
\end{tabular}

(37\%), the selected $\mathrm{KC}$ was almost three times more likely to be related than the second-most related competency, which indicated that the KCs were adequately confirmed by the participants. Finding consensus should help in defining learning outcomes for the teaching of these competencies [25, 32]. Therefore, the identification of KCs could facilitate the development of programmes and learning objectives in this field, but it is necessary to conduct more research to assess the applicability and feasibility of teaching these competencies.

The achievement of professionalism and CCS competencies KCs for both CCS and Professionalism were cited as competencies required by the end of undergraduate medical education, while an appropriate development of IC and Leadership should be attained during postgraduate study.

Within KCs for Professionalism, ethics, patient safety and humanistic values were highlighted, and more than $80 \%$ of the participants indicated that these should be achieved during the undergraduate level. Professionalism is closely linked with humanistic values, such as altruism and accountability, which encourages medical students to understand their responsibilities to their patients and their families, and society [33] and plays an important role in the practice of medicine, according to faculty and patients [34].

Reflection, critical thinking and accountability were also cited as needing to be achieved during the undergraduate level, but to a lesser extent. A doctor's capacity to adapt to a given context when dealing with uncertainty was the only $\mathrm{KC}$ clearly related to postgraduate study (residency). The Draft CanMEDS 2015 Milestones Guide [26] points out the importance of recognising uncertainty during the undergraduate period but indicated that learning to adapt to and 'deal with' uncertainty was best accomplished during residency. The development of this kind of competency requires sustained and diverse training, during which, students learn how to deal with the particularities of individual patients and their families, and team members [35].

Thus, the findings suggested a progression in the attainment of Professionalism, starting with the learning of the values of respect and ethics and the promotion of safety in medical care and then enhancing the practice to reach higher levels of skill with regard to reflection, critical thinking and accountability. Considering that none of these elements develops in a linear fashion, they have to be fostered in medical students starting early but the requirement of achieving these skills must be intensified in clinical practice.

Among the KCs for CCS, almost all, related to the patient-centred interview, were designated as important to be attained during undergraduate medical education. This reinforces the importance of teaching these skills since aspects, such as communication structure and patient orientation [36, 37], require specific training in order to achieve the best results in practice [38]. The CCS skills needed during more difficult and specific situations, such as breaking bad news, were proposed as needing to be adequately achieved during residency despite studies showing the effectiveness of teaching this skill during undergraduate and postgraduate study [39]. Frequently, newly graduated physicians must handle these kinds of situations. Therefore, despite the fact that this skill should be attained in residency, undergraduate study must provide a strong foundation for its development [40, 41].

The subjects pointed to during residency or even later in medical training as the ideal time for the attainment of Leadership and IC KCs. These competencies involve many types of clinical contexts, including the need to be able to work in a multidisciplinary team, perform consultations, resolve conflict in order to ensure patient safety, exercise basic leadership skills and engage in the management of human and healthcare resources. Therefore, a profound immersion in the responsibilities of the workplace environment is necessary during postgraduate training [42]. The achievement of significant milestones might build the principles of professional IC and Leadership, as happens with teamwork in student-student and/ or student-faculty work [26, 43]. It is important for medical schools to prioritise curricula by first bolstering and evaluating certain competencies and then ensuring a foundation upon which to later build and achieve others.

Defining when to achieve a $\mathrm{KC}$ is an important step, but the growth and fulfilment of these $\mathrm{KCs}$ in medical training needs to be better studied from the undergraduate to expert level [41], which highlights that the assessment of these $\mathrm{KCs}$, including those in the workplace, is essential and must be stimulated [44]. 
There are KCs, such as sharing in decision-making, that can be assessed and improved upon, but it is necessary to acknowledge that some level of excellence or competency could be unattainable [29]. Some of the actual and traditional evaluation methods have been insufficient to assess emergent outcomes for students' leadership, healthcare improvement and other skills [45], and the assessment of more complex competencies requires well-designed programmes [46]. The psychometric properties of rating scales for communication are mainly intermediate, even in a more controlled environment, like objective structured clinical exams [44]. Therefore, it is important to improve assessment methods for all KCs regardless of when they are achieved.

Although it is difficult to ensure that all of these KCs are achieved during undergraduate study, it is important to do so. This would also serve to support efforts made to overcome the prejudice of them being considered as personal characteristics or minor competencies; instead, medical educators must strive to value, teach and assess them correctly.

\section{Was the time to achieve competencies influenced by the participants' personal characteristics?}

A medical educator's viewpoint can be affected not only by academic evidence and standards but also by experiences and individual beliefs [47]. The participants in the current study tended to suggest a time for the attainment of competencies around the same time they believed they had ideally attained them. The completion of a residency in family medicine, the number of years spent working as a preceptor and the number of years spent working as a faculty member influenced the subjects' opinions regarding the optimal time frame for achievement of a KC.

KCs for CCS can be understood as being among the most important and challenging competencies to be developed in practice [4]; these competencies underpin the doctor-patient relationship and are linked with a physician's performance and outcomes [48]. In contrast to non-specialists, subjects who had completed a family medicine residency tended to report that CCS should be achieved later. The need for CCS skills is profoundly increased during a family medicine residency [49]. Therefore, the relevance and high stakes of CCS may explain why the participants suggested the achievement of these competencies at later periods.

The preceptors focused on providing healthcare to patients, promoting the use of a real world environment for medical students, working with technical and ethical developments in the workplace [50] and integrating healthcare skills and knowledge with education [51]. They also focused on placing students in interdisciplinary situations, working with members of various professions and introducing students and residents to this environment [51]. These professionals have experience in Leadership and IC and are probably among the best candidates to contribute to strategies for teaching these competencies. However, the preceptors' needs to develop high standards of IC may have driven them to indicate that these KCs should be achieved later.

The degree of each participant's competence was not assessed, and the competencies and levels of expertise for each $\mathrm{KC}$ certainly differed among the subjects. This must also have come into play in the results that indicated that the medical educators' attributes influenced their opinion on when they proposed that a competency should be achieved. The elements that influenced the participants' points of views on when students should attain these competencies are shown in Fig. 1.

\section{Limitations of the study}

There are two main limitations to the current study: one is the representativeness of the sample's subjects and the other is the difficulty of guaranteeing that each competency was defined in the same way by all the participants.

A definition for 'competency' was not provided, and, because there is some variety in specific definitions for this term, the meaning could have varied among the participants. Another point is that even having proceeded carefully in the thematic organisation, to define the $\mathrm{KCs}$, there were some $\mathrm{KC}$ 's that were open to various levels of personal interpretation. These KCs, therefore, can be difficult to measure and assess [44]. In addition, aside from personal interpretations, there was also the complexity of assessing and judging the level of achievement required for a $\mathrm{KC}$ in order to work as a physician, with the duties and responsibilities of the profession [52]. These biases in the definition of assessment and attainment could blur viewpoints about a competency and the best time frame for its achievement. The subject's point of view can be based not only on competencies that they consider fundamental to undergraduate students but also on their opinion of the junior doctors or registrars they supervise in their practices who have not achieved these competencies.

Considering the continental dimensions and number of medical schools in Brazil (272) [53], the 74 participants in the current study were not a representative sample of all the medical teachers in the country. However, the statistical significance for almost all of the competencies and subdomains was good and represented the opinions of this group of family physicians' medical educators. The mean age was 37.9, which is younger than in other samples of medical educators in Brazil [54]. However, the fact that residency programmes in family medicine, the 


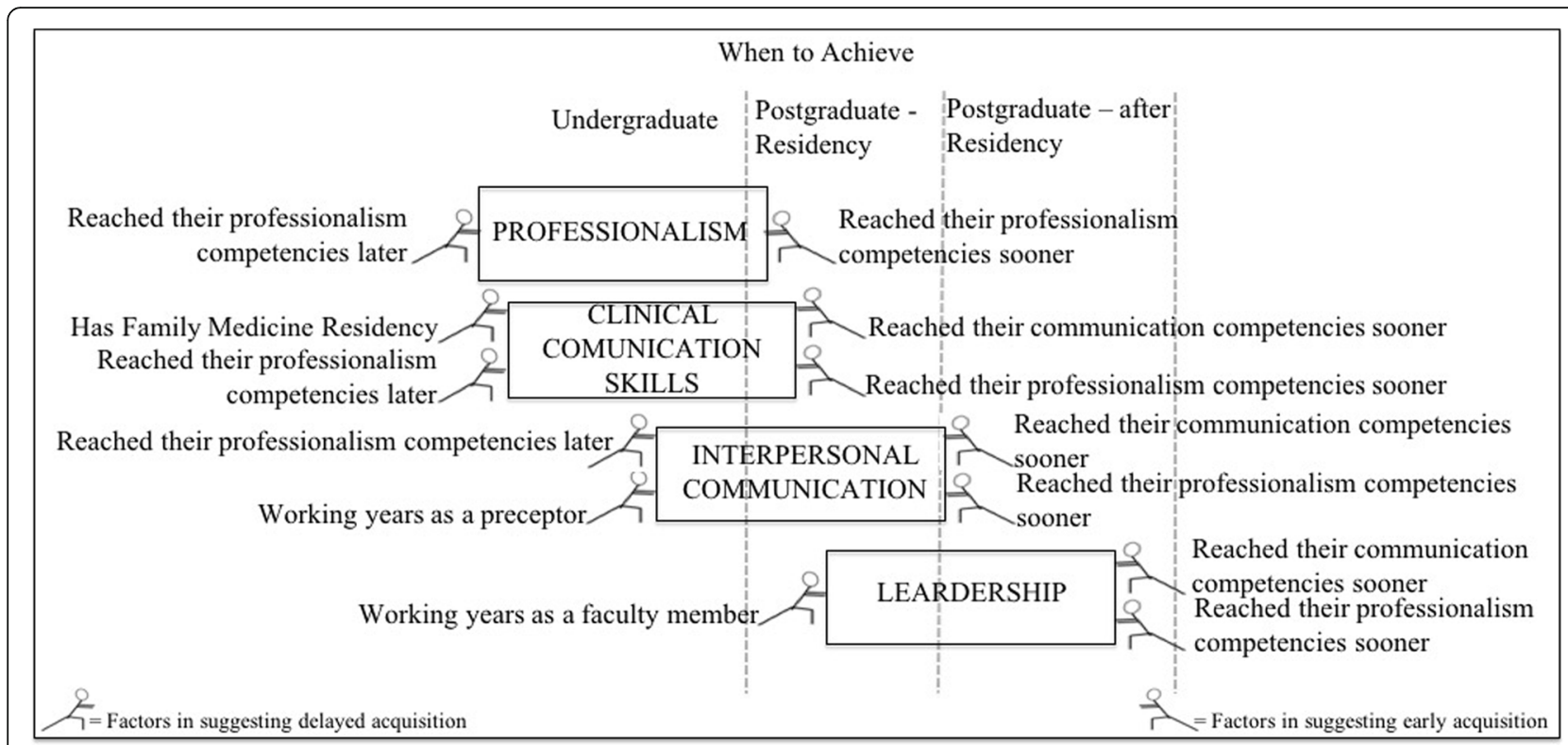

Fig. 1 Factors influencing the subjects' points of view of when students should achieve the competencies

inclusion of the discipline of family medicine in medical schools and the mastery of these doctors in medical education has become more important in Brazil in the last several years [55-57] explains the youth of the sample. Another possible bias is that family physicians frequently have specific training in communication competencies.

Therefore, these results must be analysed in light of these limitations, including, that doctors from other specialties could have different points of view.

\section{Conclusion}

It was possible to suggest an order and time frame for the development of communication and professionalism KCs during medical training. The KCs for CCS and Professionalism were indicated as needing to be achieved sooner. Following those were the IC and Leadership $\mathrm{KCs}$, the basis of which should be formed at the undergraduate level. This is because the mastery of IC and Leadership competencies demands a profound immersion in workplace and medical responsibilities.

The influence of the participants' professional experiences on their viewpoints regarding the achievement of the KCs showed that the medical educators' opinions could have been driven not only by academic knowledge of medical education but also by their own perceived personal development. On one hand, this influence can be considered biased, but on the other hand, it can be thought of as a more realistic viewpoint because it comes from people who are deeply immersed in the field.

The opinions of these family physicians' medical educators can assist with the development of required outcomes for medical training, which could drive the organisation of medical curricula and support programmes of lifelong learning. The certification of these $\mathrm{KCs}$ and improvement in assessment methods, including their impact on healthcare, are the next steps for future research.

\section{Additional file}

Additional file 1: Survey Questionnaire. (PDF $184 \mathrm{~kb}$ )

\section{Abbreviations}

CCS: clinical communication skills; IC: interpersonal communication; KCs: key competencies

\section{Acknowledgements}

Thank you to all the family physicians who participated in this research. Financial support for the authors was provided by a scholarship from the National Counsel of Technological and Scientific Development (CNPq), Brazil (229753/2013-2) and a scholarship from Coordination for the Improvement of Higher Education Personnel (CAPES), Brazil (13271/13-0).

In honour of Professor Dr. Jose Mauro Ceratti Lopes, we would like to dedicate this paper to him and his family. Professor Jose Mauro passed away on 7 July 2017, leaving behind not only family but also thousands of friends and admirers. He was not fond of long discourses or honorifics; respecting this, we will just say these few words and offer our condolences to his family.

\section{Funding}

There was no direct financial support for this research. Financial support for the authors is provided by scholarships from the National Counsel of Technological and Scientific Development (CNPq), Brazil (229753/2013-2) and the Coordination for the Improvement of Higher Education Personnel (CAPES), Brazil (13271/13-0).

\section{Availability of data and materials}

The datasets and/or analyses used for the current study are available from the corresponding author on reasonable request. 


\section{Authors' contributions}

All the authors, FCAGS, FRS, SM, FMA and LMC, believe that the manuscript represents honest work, participated in its conceptualisation and research, and critically edited the manuscript. FCAGS and FRS are responsible for the content and writing of the manuscript. SM analysed the data presented in the manuscript. All the authors are responsible for the final manuscript and are able to defend its conclusions. All authors read and approved the final manuscript.

\section{Ethics approval and consent to participate}

The Ethics Committee for Health of the Hospital São João, Portugal, approved this research, assigning it number 288/2014. Signed, informed consent forms were obtained from all participants.

\section{Consent for publication}

Not applicable.

\section{Competing interests}

The authors declare they have no competing interests.

\section{Publisher's Note}

Springer Nature remains neutral with regard to jurisdictional claims in published maps and institutional affiliations.

\section{Author details}

${ }^{1}$ School of Medicine (discipline of Family Medicine), Pontifical University of Paraná, Curitiba, Brazil. ${ }^{2}$ Department of Medical Education and Simulation, Faculty of Medicine, University of Porto, Alameda Prof. Hernâni Monteiro, 4200-319 Porto, Portugal. ${ }^{3}$ School of Medicine (discipline of Introduction to the Medical Practice), Pontifical University of Paraná, Curitiba, Brazil. ${ }^{4}$ Department of Public Health, Federal University of Health Sciences of Porto Alegre (UFCSPA), Porto Alegre, Brazil. ${ }^{5} \mathrm{Community} \mathrm{Health} \mathrm{Service} \mathrm{of} \mathrm{the} \mathrm{Conceição} \mathrm{Hospital}$ Group, R. Sarmento Leite, 245 - Centro Histórico, Porto Alegre, RS 90050-170, Brazil. ${ }^{6}$ Department of Epidemiology, Predictive Medicine and Public Health, Faculty of Medicine, University of Porto, Porto, Portugal. 'Institute of Public Health, University of Porto, Portugal. Alameda Prof. Hernâni Monteiro, 4200-319 Porto, Portugal. ${ }^{8}$ Faculty of Medicine, University of Porto, Porto, Portugal.

\section{Received: 5 October 2016 Accepted: 6 March 2018}

\section{Published online: 20 March 2018}

\section{References}

1. Benson BJ. Domain of competence: interpersonal and communication skills. Acad Pediatr Elsevier Ltd. 2014;14(2):S55-65. https://doi.org/10.1016/j.acap. 2013.11.016

2. Stewart M, Brown JB, Hammerton J, Donner A, Gavin A, Holliday RL, et al. Improving communication between doctors and breast cancer patients. Ann Fam Med Centre for Studies in Family Medicine, University of Western Ontario, London, Ont, Canada. 2007;5(5):387-94. https:/doi.org/10.1370/afm.721.

3. Cegala DJ, Lenzmeier Broz S. Physician communication skills training: a review of theoretical backgrounds, objectives and skills. Med Educ. 2002/10/31. 2002;36(11):1004-16. https://doi.org/10.1046/j.1365-2923.2002.01331.x.

4. Warnecke E. The art of communication. Aust Fam Physician. 2014;43(3):156-8. https://doi.org/10.1016/j.optm.2007.09.008.

5. Hawken SJ. Good communication skills: benefits for doctors and patients. Contin. Med Educ. 2005;32(3):185-9.

6. Peskin T. Malpractice, patient satisfaction, and physician-patient communication JAMA J Am Med Assoc. 1995;274(1):22. https://doi.org/10.1001/jama. 1995.03530010036017

7. Mikesell L. Medicinal relationships: caring conversation. Med Educ. 2013; 47(5):443-52. https://doi.org/10.1111/medu.12104.

8. ABIM Foundation. American Board of Internal Medicine, ACP-ASIM Foundation American College of Physicians-American Society of internal medicine, European Federation of Internal Medicine. Medical professionalism in the new millennium: a physician charter. Ann Intern Med. 2002;136(3): 243. https://doi.org/10.7326/0003-4819-136-3-200202050-00012.

9. Brown J. How clinical communication has become a core part of medical education in the UK. Med Educ. 2008;42(3):271-8. https://doi.org/10.1111/j. 1365-2923.2007.02955.x.

10. Shield RR, Tong I, Tomas M, Besdine RW. Teaching communication and compassionate care skills: an innovative curriculum for pre-clerkship medical students. Med Teach. 2011;33(8):e408-16. https://doi.org/10.3109/0142159X. 2011.586748.

11. Lee $\mathrm{Y}$-M, Lee $\mathrm{YH}$. Evaluating the short-term effects of a communication skills program for preclinical medical students. Korean J Med Educ. 2014;26(3): 179-87. https://doi.org/10.3946/kjme.2014.26.3.179.

12. Jameel A, Noor SM, Ayub S, Ali SS, Park YS, Feasibility TA. Relevance and effectiveness of teaching and assessment. J Pak Med Assoc. 2015;65(7):721-6.

13. Dedy NJ, Bonrath EM, Zevin B, Grantcharov TP. Teaching nontechnical skills in surgical residency: a systematic review of current approaches and outcomes. Surgery. 2013/06/20. 2013;154(5):1000-8. https//doi.org/10.1016/j.surg.2013.04.034.

14. Sari MI, Prabandari YS, Claramita M. Physicians' professionalism at primary care facilities from patients' perspective: the importance of doctors' communication skills. J Fam Med Prim care. 2016:5(1):56-60. https://doi.org/10.4103/2249-4863.184624.

15. Turkeshi E, Michels NR, Hendrickx K, Remmen R. Impact of family medicine clerkships in undergraduate medical education: a systematic review. BMJ Open. 2015;5(8):e008265. https://doi.org/10.1136/bmjopen-2015-008265.

16. Pearson DJ, McKinley RK. Why tomorrow's doctors need primary care today. JRSM. 2010;103(1):9-13. https://doi.org/10.1258/jrsm.2009.090182.

17. Brasil. Ministério da Educação, Conselho Nacional de Educação C de ES, Brasil. Diretrizes Curriculares Nacionais do Curso de Graduação em Medicina. [Internet]. Homol em 03/10/2001, Parec CES 1133/2001, Resolução CNE/CES $N^{\circ}$ 4, 7/11/2001. 2001. p. 1-6. Available from: http://portal.mec.gov.br/ dmdocuments/ces1133.pdf

18. Brasil. Ministério da Educação, Conselho Nacional de Educação C de ES. Brasil Ministério da Educação, Conselho Nacional de Educação, Câmara de Educação Superior. [Internet]. Resolução n3, CNE/CES 20/06/2014 Institui diretrizes curriculares Nac do curso Grad em Med. 2014. Available from: http://portal.mec.gov.br/index.php?option=com_docman\&task=doc_ download\&gid=15514\&ltemid=

19. Turini B, Martins Neto D, Tavares M de S, Nunes SOV, da SVLM, Thomson Z. Comunicação no ensino médico: estruturação, experiência e desafios em novos currículos médicos. Rev Bras Educ Med. 2008:32(2):264-70. https://doi. org/10.1590/S0100-55022008000200015.

20. Swing SR. The ACGME outcome project: retrospective and prospective. Med Teach. 2007;29(7):648-54. https://doi.org/10.1080/01421590701392903.

21. Australian Medical Council. Standards for Assessment and Accreditation of Primary Medical Programs by the Australian Medical Council [Internet]. 2012. p. 14. Available from: http://www.amc.org.au/files/d0ffcecda9608cf 49c66c93a79a4ad549638bea0_original.pdf

22. Kiessling C, Dieterich A, Fabry G, Holzer H, Langewitz W, Muhlinghaus I, et al. Communication and social competencies in medical education in German-speaking countries: the Basel consensus statement. Results of a Delphi survey. Patient Educ Couns. 2010/03/13. 2010;81(2):259-66. https://doi.org/10.1016/j.pec.2010.01.017.

23. Kurtz SM, Silverman JD. The Calgary-Cambridge referenced observation guides: an aid to defining the curriculum and organizing the teaching in communication training programmes. Med Educ. 1996;30(2):83-9. https:// doi.org/10.1111/j.1365-2923.1996.tb00724.x.

24. Makoul G. Essential elements of communication in medical encounters: the Kalamazoo consensus statement. Acad Med. 2001;76(4):390-3.

25. Bachmann C, Abramovitch H, Barbu CG, Cavaco AM, Elorza RD, Haak R, et al, A European consensus on learning objectives for a core communication curriculum in health care professions. Patient Educ Couns. Elsevier Ireland Ltd. 2013;93(1):18-26. https://doi.org/10.1016/j.pec.2012.10.016.

26. Frank JR, Snell LS, Sherbino J, Al E. The Draft CanMEDS 2015 Milestones guide - September 2014. [internet]. Ottawa R Coll physicians Surg Canada. Ottawa; 2014. Available from: http://www.royalcollege.ca/rcsite/documents/ canmeds/canmeds-2015-framework-series-3-e.pdf

27. General Medical Council. Tomorrow's Doctors: outcomes and standards for undergraduate medical education [Internet]. Manchester, UK; 2009. p. 104 Available from: http://www.gmc-uk.org/Tomorrow_s_Doctors_1214.pdf 48905759.pdf

28. Victorino R, Jollie C, McKim J. O Licenciado Médico em Portugal. Core Graduates Learning Outcomes Project [Internet]. Lisboa Fac Med Lisboa 2005. Available from: https://sigarra.up.pt/fmup/pt/web_gessi_docs.download file?p_name=F2055226585/licenciadomedico_portugal2005-2.pdf

29. Cooke M, Irby DM, O'Brien BC, Shulman LS. Educating physicians: a call for reform of medical school and residency. San Francisco: Jossey-Bass. Wiley; 2010.

30. Birden H, Glass N, Wilson I, Harrison M, Usherwood T, Nass D. Defining professionalism in medical education: a systematic review. Med Teach. 2014;36(1):47-61. https://doi.org/10.3109/0142159X.2014.850154. 
31. Franco RS, Franco CAGDS, Severo M, Ferreira MA, Ament C, Franco S, et al. General competences on medical professionalism: is it possible? Med Teach Informa UK Ltd London. 2015;37(10):1. https://doi.org/10.3109/0142159X. 2015.1045853

32. García de Leonardo C, Ruiz-Moral R, Caballero F, Cavaco A, Moore P, Dupuy $L P$, et al. A Latin American, Portuguese and Spanish consensus on a core communication curriculum for undergraduate medical education. BMC Med Educ. 2016;16(1):99. https://doi.org/10.1186/s12909-016-0610-8.

33. Swick HM, Szenas P, Danoff D, Whitcomb ME. Teaching professionalism in undergraduate medical education. JAMA. 1999;282(9):830-2. https://doi.org/ 10.1001/jama.282.9.830.

34. Walsh S, Arnold B, Pickwell-Smith B, Summers B. What kind of doctor would you like me to be? Clin Teach. 2015;n/a-n/a. doi:https:/doi.org/10.1111/tct.12389.

35. Warren AE, Allen VM, Bergin F, Hazelton L, Alexiadis-Brown P, Lightfoot K, et al. Understanding, teaching and assessing the elements of the CanMEDS Professional Role: Canadian Program Directors' views. Med Teach. 2014/03/ 08. 2014; https://doi.org/10.3109/0142159x.2014.890281.

36. MJ Y, CC G, Kachur E, MD S, Ockene J, AE C, et al. Effect of communications training on medical student performance. JAMA. 2003/09/04. 2003;290(9): 1157-65. https://doi.org/10.1001/jama.290.9.1157.

37. Simmenroth-Nayda A, Heinemann S, Nolte C, Fischer T, Himmel W. Psychometric properties of the Calgary Cambridge guides to assess communication skills of undergraduate medical students. Int J Med Educ. 2014;5:212-8. https://doi.org/10. 5116/ijme.5454.c665.

38. M van Es J, Wieringa-de Waard M, Visser MRM. Differential growth in doctorpatient communications skills. Med Educ 2013;47(7):691-700. https:/doi.org/ 10.1111/medu. 12175 .

39. Alelwani SM, Ahmed YA. Medical training for communication of bad news: a literature review. J Educ Health Promot. 2014;3(June):1-5. https://doi.org/ 10.4103/2277-9531.134737.

40. Reed S, Kassis K, Nagel R, Verbeck N, Mahan JD, Shell R. Breaking bad news is a teachable skill in pediatric residents: a feasibility study of an educational intervention. Patient Educ Couns Elsevier Ireland Ltd. 2015;98(6):748-52. https://doi.org/10.1016/j.pec.2015.02.015.

41. Wouda JC, van de Wiel HBMM. The communication competency of medical students, residents and consultants. Patient Educ Couns. Elsevier Ireland Ltd. 2012;86(1):57-62. https://doi.org/10.1016/j.pec.2011.03.011.

42. Mckinlay EM, App MA, Gallagher PA, Gray LA, Wilson CL, Pullon SRH. Sixteen Months "From Square One ": The Process of Forming an Interprofessional Clinical Teaching Team. 2015;5:9-12.

43. Komattil R, Hande SH, Mohammed CA, Subramaniam B. Evaluation of a personal and professional development module in an undergraduate medical curriculum in India. Korean J Med Educ. 2016;28(1):117-21. https://doi.org/10.3946/kjme.2016.17.

44. Cömert M, Zill JM, Christalle E, Dirmaier J, Härter M, Scholl I. Assessing communication skills of medical students in objective structured clinical examinations (OSCE) - a systematic review of rating scales. Hills RK. PLoS One. 2016;11(3):e0152717. https://doi.org/10.1371/journal.pone.0152717.

45. Jorm C, Roberts C. Using complexity theory to guide medical school evaluations. Acad Med. 2017;1 https://doi.org/10.1097/ACM.0000000000001828.

46. Favia A, Frank L, Gligorov N, Birnbaum S, Cummins P, Fallar R, et al. A model for the assessment of medical students' competency in medical ethics. AJOB Prim Res. 2013:4(4):68-83. https://doi.org/10.1080/21507716.2013.768308.

47. Dalgaty F, Guthrie G, Walker H, Stirling K. The value of mentorship in medical education. Clin Teach. 2017;14(2):124-8. https:/doi.org/10.1111/tct.12510.

48. WONCA Europe. The European Definition of General Practice / Family Medicine - Edition 2011 [Internet]. 2011. p. 1-33. Available from: http:// www.woncaeurope.org/content/european-definition-general-practicefamily-medicine-edition-2011

49. Green LA, Jones SM, Fetter G, Pugno PA. Preparing the personal physician for practice: changing family medicine residency training to enable new model practice. Acad Med. 2007;82(12):1220-7. https://doi.org/10.1097/ACM. Ob013e318159d070.

50. de Oliviria B, Henrique S, Tavares de Almeida Rego S. Docente-clínico: o complexo papel do preceptor na residência médica. Clinical teacher: the complex role of the preceptor in medical residency. Physis Rev Saúde Coletiva. 2011;21(1):65-85. https://doi.org/10.1590/S0103-73312011000100005.

51. Autonomo FR de OM, Hortale VA, dos SGB, Botti SH de O. A Preceptoria na Formação Médica e Multiprofissional com Ênfase na Atenção Primária Análise das Publicações Brasileiras. Primary Health Care Preceptorship in Medical and Multidisciplinary Training - A Review of Brazilian Publications
Rev Bras Educ Med. 2015;39(2):316-27. https://doi.org/10.1590/1981$52712015 v 39 n 2 e 02602014$.

52. Gonsalves C, Zaidi Z. Hands in medicine: understanding the impact of competency-based education on the formation of medical students' identities in the United States. J Educ Eval Health Prof. 2016;13:31. https://doi.org/10.3352/jeehp.2016.13.31.

53. Ministério da Educação e Cultura, Ministerio da Educação e Cultura B. Instituições de Educação Superior e Cursos Cadastrados. Institutions of Higher Education. [Internet]. Cadastro Instituições Regist Institutions. 2017. Available from: http://portal.mec.gov.br/instituicoes-credenciadas

54. Souto LES, Souza SM, Lima C de A, Lacerda MKS, Vieira MA, da CFM, et al. Fatores Associados à Qualidade de Vida de Docentes da Área da Saúde. Rev Bras Educ Med. 2016;40(3):452-60. https://doi.org/10.1590/1981-52712015v40n 3e02362014.

55. Martín Meoño T, Padula Anderson Ml, Cuadrado Segura M, Araya Via P. A Medicina de Família e Comunidade como Eixo da Universalidade nos Sistemas de Saúde de Ibero-América: uma análise exploratoria da região. Family and Community Medicine as the core of Health Systems Universality in Latin America: an exploratory analys. Rev Bras Med Família e Comunidade. 2016;11(Suppl 2):4. https://doi.org/10.5712/rbmfc11(0)1382.

56. Coppolillo F, Jure H, Ciuffolini MB, Yuruhán D. Fortalecimiento del proceso de enseñanza aprendizaje de la Medicina Familiar y Comunitaria en Iberoamérica. Strengthening the teaching-learning process of Family and Community Medicine in Iberoamerica Rev Bras Med Família e Comunidade. 2016;11(Suppl 2):46. https://doi.org/10.5712/rbmfc11(0)1385.

57. Governo Federal - Federal Government. MS e MEC apoiam formação de docentes e preceptores. Ministry of Heath and Ministry of Education and Culture support the training of teachers and preceptors. [Internet]. Mais Médicos. 2015. p. 1. Available from: http://maismedicos.gov.br/noticias/213ministerios-da-saude-e-da-educacao-apoiam-formacao-de-docentes-epreceptores

\section{Submit your next manuscript to BioMed Central and we will help you at every step:}

- We accept pre-submission inquiries

- Our selector tool helps you to find the most relevant journal

- We provide round the clock customer support

- Convenient online submission

- Thorough peer review

- Inclusion in PubMed and all major indexing services

- Maximum visibility for your research

Submit your manuscript at www.biomedcentral.com/submit

) Biomed Central 